\title{
Entrepreneurial orientation, learning orientation, market orientation, and organizational performance: Family firms versus non-family firms
}

\author{
Remedios Hernández-Linares ${ }^{\mathrm{a} *}$, María Concepción López-Fernández \\ a University of Extremadura, España \\ b University of Cantabria, España
}

JEL
CLASSIFICATION
M1
KEYWORDS
Strategic
orientation,
entrepreneurial
orientation,
learning
orientation, market
orientation,
performance,
family firm

\section{CÓDIGOS JEL \\ M1}

PALABRAS CLAVE
Orientación
estratégica,
orientación
emprendedora,
orientación al
aprendizaje,
orientación
al mercado,
performance,
empresa familiar

\begin{abstract}
Firms develop and use multiple strategic orientations. However, few studies have considered more than one strategic orientation, and such studies have paid limited attention to the singular context of family firms, despite the growing evidence of these firms' special strategic behavior. To address these research gaps, we analyze the combined effects of three strategic orientations (entrepreneurial orientation, learning orientation, and market orientation) on family firms' performance by comparing family firms and non-family firms from Spain and Portugal. Our results show differences in the strategic behavior of family firms, but we do not find differences in performance, corroborating the idea of strategic equifinality.
\end{abstract}

Orientación emprendedora, orientación al aprendizaje, orientación al mercado y performance: empresas familiares versus empresas no familiares

Resumen Las empresas desarrollan y utilizan múltiples orientaciones estratégicas. Sin embargo, pocos estudios han considerado más de una orientación estratégica y los existentes han prestado escasas atención las empresas familiares, a pesar de la creciente evidencia del comportamiento estratégico diferencial de estas empresas. Para cubrir este gap en la investigación, analizamos los efectos combinados de tres orientaciones estratégicas (orientación emprendedora, orientación al aprendizaje y orientación al mercado) en la performace de las empresas familiares comparando empresas familiares y no familiares de España y Portugal. Nuestros resultados muestran diferencias en el comportamiento estratégico de las empresas familiares, pero no encontramos diferencias en el desempeño, lo que corrobora la idea de la equifinalidad estratégica.

https://doi.org/10.24310/ejfbejfb.v10i1.6780

Copyright 2020: Remedios Hernández-Linares, María Concepción López-Fernández

European Journal of Family Business is an open access journal published in Malaga by UMA Editorial. ISSN 2444-8788 ISSN-e 2444-877X This work is licensed under a Creative Commons Atribution-NonCommercial-ShareAlike 4.0 International License (CC BY-NC-SA 4.0). 


\section{Introduction}

The relationship between different strategic orientations and performance has been a subject of strong research interest. Most studies have investigated the direct linkage between firm performance and a specific strategic orientation, mainly market orientation (MO) (e.g., Kohli, Jaworski, \& Kumar, 1993; Morgan, Vorhies, \& Mason, 2009), entrepreneurial orientation (EO) (e.g., Keh, Nguyen, \& Ng, 2007; Wiklund \& Shepherd, 2003), and learning orientation (LO) (e.g., Calantone, Cavusgil, \& Zhao, 2002; Lam, Lee, Ooi, \& Lim, 2011). This perspective remains incomplete and problematic as organizations may employ multiple strategic orientations (Cadogan, 2012; Lonial \& Carter, 2015; Wang, 2008). Consequently the potential of each orientation should not be viewed in isolation (e.g., Lonial \& Carter, 2015). However the joint potential of different orientations has received only fragmented attention from scholars, representing a research gap that should be covered in the literature (Deutscher, Zapkau, Schwens, Baum, \& Kabst, 2016; Hakala, 2011). In addition, this scant research has largely ignored the singular context of family firms, despite its worldwide predominance (Sharma, Chrisman, \& Gersick, 2012) and its uniqueness in terms of strategic behavior (Carney, van Essen, Gedajlovic, \& Heugens, 2015). Therefore, an important gap remains in our understanding of how family control affects strategic behavior and how the strategic behavior affects performance (Carney et al., 2015). The study of strategic orientations in the family firm literature is limited to an emerging body of literature focusing on EO (Hernández-Linares \& López-Fernández, 2018), a handful of papers studying MO (e.g., Newman, Prajogo, \& Atherton, 2016; Tokarczyk, Hansen, Green, \& Down, 2007; Zachary, McKenny, Short, \& Payne, 2011), and only one work researching LO (Hernández-Linares, Kellermanns, \& López-Fernández, 2018a). However, none of the extant works have researched the combined influence of these three orientations on family firm performance.

To contribute to filling these research gaps, this study pursues a twofold objective: First, to analyze the combined effects of three strategic orientations (EO, LO, and $\mathrm{MO}$ ) on family firm performance. Second, to compare the combined effects of these three orientations on the organizational performance of both family and non-family firms to determine whether the idea of strategic equifinality - proposed by Carney et al. (2015) and defined by them as the achievement of similar performance outcomes by following significantly different strategies - may be also applied when these three strategic orientations (EO, LO, and MO) are considered. To perform the empirical work, we use a unique database consisting of responses from top executives from a sample of 1,066 small- and medium-enterprises (SMEs) from Portugal and Spain.

We contribute to both the strategy and family business literature in at least three ways. First, this is the first work that comprehensively studies the relationships between these three strategic orientations and organizational performance by comparing family and non-family firms. This broadens our limited knowledge about the relationships between different strategic orientations (Deutscher et al., 2016; Hakala, 2011) by corroborating the influence of the family firm status that had been reported by Hernández-Linares et al. (2018a). Second, our results confirm both the different strategic behavior of family firms and the lack of consequences on performance outcomes, adding empirical evidence to the strategic equifinality idea (Carney et al., 2015). Third, we contribute to the scant literature on LO and MO in family firms by, for the first time, employing performance as the dependent variable in empirical research carried out with private firms. These results will allow family firms to focus their efforts on those strategic orientations that contribute more to their organizational success.

In the sections that follow, we first present the theoretical framework and the research hypotheses. Then, we describe the methodology. Finally, we discuss the results, we discuss the results and implications, and we propose future research lines.

\section{Theoretical Framework}

As a way to operationalize the strategy of the firm, the concept of strategic orientation has been identified as a key term within management literature and has attracted widespread attention from management, marketing, and entrepreneurship scholars (Hakala, 2011). Despite there being no definitive view of the conceptualization and nature of strategic orientations, EO, LO, and $\mathrm{MO}$ are the more consolidated constructs in the literature (Deutscher et al., 2016; Hakala, 2011). Hakala (2011) explored the different approaches followed by management literature to study the interactions between different strategic orientations, and he identified three approaches: sequential and alternative approaches, which only consider a strategic orientation at a time and a complementary approach, which considers that organizations may have several orientations simultaneously and views orientations as flexible constructs that are combined into universally beneficial or contingency-related patterns. In this paper, we follow this third approach by analyzing the parallel direct effects of these three strategic orientations on family firm performance. 
The promise of the EO concept lies in its ability to further our understanding of the entrepreneurial activities pursued by organizations (Covin \& Wales, 2012). The literature reflects a significant interest in examining how EO affects organizational performance (Rauch, Wiklund, Lumpkin, \& Frese, 2009). Although some studies have found this impact to be negative (e.g., Matsuno, Mentzer, \& Özsomer, 2002; Slevin \& Covin, 1990), the larger body of evidence argues that firms adopting a more entrepreneurial strategic orientation have the ability to pursue new market opportunities to respond to the changing environment, to gain greater competitive advantage ahead of other competitors, and hence, to achieve superior performance, with EO being a key ingredient for the organizational success (e.g., Wiklund, 1999; Zahra \& Covin, 1995).

However, the presence of the family as the dominant coalition of the firm is expected to affect goal-setting in family firms (Chrisman et al., 2012; Kotlar \& De Massis, 2013) with family-oriented goals (both economic and non-economic) playing a relevant role. Despite the limited literature related to EO, family firm performance and family oriented goals (Hernández-Linares \& López-Fernández, 2018), there is some evidence to suggest that EO is conducive to both economic and non-economic goals (Irava \& Moores, 2010; Revilla, Pérez-Luño, \& Nieto, 2015). Similarly, the long-term orientation of family firms is at the root of their ability to succeed and survive despite their lower level of EO (Lumpkin, Brigham, \& Moss, 2010; Miller, Steier, \& Le Breton-Miller, 2016).

The scant empirical investigations focusing on the EO-performance within family firms present contradictory findings. Some scholars find either that EO has no significant effect on family firm performance (Madison, Runyan, \& Swinney, 2014), or that risk-taking (Naldi, Nordqvist, Sjöberg, \& Wiklund, 2007) and innovativeness (HernándezLinares, Kellermanns, López-Fernández, \& Sarkar, 2019), two dimensions of EO, are negatively related to performance. However, other scholars find a positive impact of EO on family firm performance (Chien, 2014; Lee \& Chu, 2017; Schepers, Voordeckers, Steijvers, \& Laveren, 2014). In line with this last group of researchers, and following the theoretical arguments that point toward a positive effect of EO in family firm performance, we hypothesize the following:

Hypothesis 1. Entrepreneurial orientation is positively associated with family performance.

Research on LO is extensive and seems to confirm that firms that learn from their successes and mistakes through experience tend to be more successful (Hult, Nichols, Giunipero, \& Hurley, 2000; Kropp, Lindsay, \& Shoham, 2006; Zahra, Ireland, \& Hitt, 2000). Thus, though some studies do not find a significant relationship between LO and market performance (Lam et al., 2011) and others reveal that LO has no direct effect on firm performance (Lin, Peng, \& Kao, 2008), the research generally reports that LO facilitates the generation of resources and skills essential for enhancing business performance through its influence on competitive advantage (e.g., Baker \& Sinkula, 1999; Calantone et al., 2002; Farrell, Ockowski, \& Kharabsheh, 2008; Kropp et al., 2006; Mavondo, Chimhanzi, \& Stewart, 2005; Real, Roldán, \& Leal, 2014).

"The only thing that gives an organisation a competitive edge - the only thing that is sustainable is what it knows, how it uses what it knows, and how fast it can know something new" (Prusak, 1996, p. 6). Despite this, and despite the importance of knowledge as a source of competitive advantage in family business (Cabrera-Suárez, De Saá-Pérez, \& García-Almeida, 2001), the relationship between LO and family firm performance remains as a research gap. However, the literature informs us that learning allows organizations to generate new knowledge for building new skills and capabilities that could lead to competitive advantage (Chirico, 2008; Zahra, 2012; Zahra, Neubaum, \& Larrañeta, 2007), and "allows tasks to be performed more effectively" (Teece, 2014, p. 333). Taking these arguments into consideration, and also considering that family firms communicate and exchange information more efficiently that do their non-family counterparts (Habbershon \& Williams, 1999) and that the family business status impacts the translation of LO in EO (Hernández-Linares et al., 2018a), which has been mostly linked to performance (Rauch et al., 2009), we formally hypothesize:

Hypothesis 2. Learning orientation is positively associated with family firm performance.

Bearing in mind that the $M O$ requires the commitment of resources, this orientation is useful only if the benefits it affords exceed the cost of those resources (Kohli \& Jaworski, 1990). For this reason, the relationship between $M O$ and business performance constitutes a critical question for the literature. Some researchers have reported either non-significant or negative effects for this association (e.g., Bhuian, 1997; Greenley, 1995; Grewal \& Tansuhaj, 2001). However, in general, there is strong support for the existence of a positive relationship between these two variables (e.g., Baker \& Sinkula, 2009; Desphandé, Farley, \& Webster, 1993; Farrell et al., 2008; Jaworski \& Kohli, 1993; Kumar, Jones, Venkatesan, \& Leone, 
2011; Narver \& Slater, 1990), as was confirmed by the meta-analysis performed by Kirca and colleagues (2005). These studies seem to corroborate that $M O$ is vital to an organization in that it helps to assess the constraints and opportunities created by the environment (Kumar et al., 2011) and support the widely held marketing notion that the attainment of business goals is achieved by satisfying the needs of customers more efficiently and effectively than can competitors (Rodríguez, Carrillat, \& Jaramillo, 2004).

MO is influenced by an organization's characteristics (Kirca, Jayachandran, \& Bearden, 2005; Matsuno et al., 2002). However, and despite strategic singularities of family businesses (Carney et al., 2015), the literature on $M O$ and family firms is extremely limited. Among these scarce studies, and as a result of their case study with eight family firms, Tokarczyk and colleagues (2007) inform that familiness "by virtue of multiple inherent distinct qualities and resources is positively associated with creation of an environment that promotes a market-oriented culture" (p. 30) and that this culture does play a positive and significant role in the overall long-term financial success of businesses. In similar fashion, in the only quantitative study linking family firms' performance to MO, Zachary et al. (2011) point that there is a positive relationship between $\mathrm{MO}$ and family firm performance. Based on the above arguments, we propose the following hypothesis:

Hypothesis 3 . Market orientation is positively associated with family firm performance.

As a second step in our paper, we compare the combined effects of EO, LO, and MO on the organizational performance of family and non-family firms to try to shed light on the influence of the family control on the strategic behavior and on how the strategic behavior of family firms affects their performance.

Research is consistent in showing that the strength of the relationships between strategic orientations and firm performance depends on various contingencies, such as the characteristics of organizations (e.g., Kirca et al., 2005; Matsuno et al., 2002). Family businesses are unique regarding their organizational characteristics, because they are governed by a particular set of norms, cultures, and processes not present in non-family enterprises that reflect how they manage and deploy their resources (Eddleston, Kellermanns, \& Sarathy, 2008; Kellermanns, Eddleston, Sarathy, \& Murphy, 2012).

Much of the research assessing the effect of the family character of firms on their performance relies on the premise that family firms differ from other types of firms and that these differ- ences matter for their performance (Gedajlovic, Carney, Chrisman, \& Kellermanns, 2012). In the case of EO, evidence consistently suggests a lower level of EO among family firms (Hernández-Linares \& López-Fernández, 2018). MO has also been found to be lower among family firms (Zachary et al., 2011), whereas the level of LO among family firms remains as a research gap. These results point toward a different configuration of strategic orientations among family firms. This situation is similar to either the lower level of R\&D investment or the lower international diversification (Carney et al., 2015) found previously.

However, these differences do not necessarily mean that family businesses have worse results. In the case of EO, the only strategic orientation with adequate literature, the lower level of EO in family firms does not impede their success (Miller et al., 2016), and there is no consistent evidence of worse results among family firms (HernándezLinares \& López Fernández, 2018). Besides, two recent meta-analyses inform us that there is not empirical evidence of a significant effect of family control on firm performance for family firms (Carney et al., 2015; O'Boyle, Pollack, \& Rutherford, 2012). Specifically, Carney and colleagues (2015) confirm that, despite the differences in the strategic behavior of private family firms, they did not find significant differences in the performance of family and non-family firms. The overall lack of significant differences in the performance of family and non-family firms points toward the existence of compensatory agency benefits or competitive advantages in family firms that allow them to overcome their performance deficiencies (Carney et al., 2015; Gedajlovic \& Carney, 2010). This seems to mean that strategic equifinality is also a reality among family firms and there is no "one best way" of making decisions: equifinality being defined as the state of achieving a particular outcome through various paths or configurations (Carney et al., 2015; Gresov \& Drazin, 1997; Payne, 2006). In line with these meta-analyses, we think that the associations between the three strategic orientations outlined above (EO, LO, and MO) and firm performance will lead to similar performance of both types of companies. This suggests the following hypothesis:

Hypothesis 4. The combined effect of EO, LO, and $M O$ on firm performance will be similar for family firms and for non-family firms.

\section{Method}

\section{Research design and data collection}

The data for this study, which is part of a wider research project (e.g., Hernández-Linares et al., 
2018a, 2019; Stanley et al., 2019), were collected using a survey instrument, which is consistent with previous studies (e.g., Barros, Hernangómez, \& Martín-Cruz, 2017). We employed cross-sectional designs, which are common in this field (e.g., Casillas, Moreno, \& Barbero, 2011) and we conducted the study during the first half of 2015, when the Iberian Peninsula was experiencing an important economic crisis.

Similar to prior research, we define SMEs as nonlisted private companies with 10-249 employees (e.g., Naldi et al., 2007). Our target firms came from the SABI database (Sistema de Análisis de Balances Ibéricos-System of Iberian Balance Sheets), which includes information on 1,366,768 Spanish and 536,014 Portuguese societies (March, 2015) and has been used earlier in family firm investigations (e.g., Galego, Mira, \& Vidigal da Silva, 2018). Overall, the population of this study consisted of 127,174 SMEs across all sectors.

Our questionnaire was first developed in English, then translated into Spanish and Portuguese, and then translated back into English to check for consistency. Both versions were pre-tested in the respective countries. Given that we focus on strategic issues, we relied on the CEOs or top managers as key informants, as they receive information from a wide range of departments and, therefore, are a very valuable source for evaluating the different variables of the company. Personalized invitations to complete an online, telephone, and paper survey were sent, including an offer to share summary reports as an incentive. In total, of the 27,176 companies randomly selected from the database, 1,484 surveys were completed, yielding an initial response rate of $5.46 \%$. After excluding those surveys that were not completed by either the CEO or some top manager, 1,066 surveys were usable (509 from Spanish firms and 557 from Portuguese firms), resulting in a final response rate of $3.92 \%$, which is comparable to similar studies involving top management teams in Europe (e.g., Mazzola,
Sciascia, \& Kellermanns, 2013). The sampling error was $2.99 \%$ using $95 \%$ confidence limits ( $z=$ 1.96; $\mathrm{p}=\mathrm{q}=0.5$ ).

Among the large number of criteria for delimitating the family business concept that the literature offers (Hernández-Linares, Sarkar, \& Cobo, 2018b; Hernández-Linares, Sarkar, \& LópezFernández, 2017), we used an objective criterion (ownership) and another subjective criterion (self-definition), similar to Casillas, Moreno, and Barbero (2010). Thus, we classified as family businesses all those where the family had, at least, $50 \%$ of the ownership and that were perceived as family firms by their top managers. According to these criteria, we considered 609 SMEs (57.13\%) to be family businesses, and $457(42.87 \%)$ to be non-family businesses. The main characteristics of the sample are presented in Table 1.

\section{Measures}

All constructs were measured using Likert-type scales with a five-point response format, ranging from "strongly disagree" to "strongly agree," unless otherwise noted. The internal consistency was estimated using Cronbach's alpha. In our study, Cronbach's alpha values for all measures were well above 0.80 , surpassing the threshold point of 0.7 (Nunnally, 1978).

Dependent variable. We used perceptual performance judgments to assess family business performance because subjective measures of performance yield more holistic evaluations and capture more than does a single performance element (Rodríguez et al., 2004); and a strong correlation exists between objective and subjective performance measures (Dess \& Robinson, 1984). Considering performance to be an inherently multidimensional construct (Cameron, 1978), we employed the five-item scale from HernándezLinares et al. (2019). Five-point responses ranged from "much worse" to "much better," and the Cronbach's alpha of the scale was 0.834 .

Independent variables. EO (Cronbach's alpha =

Table 1. Characteristics of the sample: family firms versus non-family firms

$\begin{array}{llcc} & & \text { Family Firms } & \text { Non-family Firms } \\ \text { Percentage of firms by country } & \text { Spain } & 58.3 \% & 41.7 \% \\ & \text { Portugal } & 56 \% & 44 \% \\ \text { Sector distribution } & \text { Primary sector } & 2.6 \% & 2.2 \% \\ & \text { Manufacturing sector } & 28.9 \% & 25.8 \% \\ & \text { Construction sector } & 9.7 \% & 7.7 \% \\ & \text { Service sector } & 58.8 \% & 64.3 \% \\ \text { Mean (standard deviation) firm size (employees) } & 33.94(35.07) & 37.74(38.39) \\ \text { Mean (standard deviation) firm age } & 24.70(14.38) & 20.829(14.03) \\ \text { Mean (standard deviation) strategic planning } & 0.62(0.49) & 0.72(0.45) \\ \text { Mean environmental dynamism } & 3.6267(0.91) & 3.6878(0.90)\end{array}$


0.876) was considered as a linear sum of dimensions, akin to Miller (1983) and Covin and Slevin (1989), but including both their three original dimensions (risk-taking, innovativeness, and proactiveness) and competitive aggressiveness and autonomy (Lumpkin \& Dess, 1996). For this operationalization, EO was measured using the eighteen-item scale of Hughes and Morgan (2007), recently applied in the family business field (e.g., Stanley et al., 2019).

LO (Cronbach's alpha $=0.866)$ was measured by adapting the accepted eleven-item scale of Sinkula, Baker, and Noordewier (1997), which has been retested and validated by various scholars (e.g., Real et al., 2014).

MO (Cronbach's alpha $=0.839$ ) was assessed by using the MORTN scale of Desphandé and Farley (1998), which includes ten items originally developed by three separate scales (Desphandé, Farley, \& Webster, 1993; Kohli et al., 1993; Narver \& Slater, 1990). Desphandé and Farley (1998) retested these three scales and synthesized them into a new and more parsimonious scale.

Control variables. We first controlled for the influence of national context on the strategic behavior of firms because, although a certain degree of homogeneity exists within the Iberian Peninsula, we cannot discount for either some cultural specificities or unobserved heterogeneity among countries that may influence the development of firms' strategic orientations (Hofstede, 2001). Spain was coded as 0 and Portugal as 1. As larger firms might have more slack resources and easier access to external resources (Zahra, Hayton, \& Salvato, 2004), we then controlled for firm size by using number of employees, whose log (ln) was taken to minimize kurtosis (Kraiczy, Hack, \& Kellermanns, 2014). We also controlled for industry type because businesses in different industries may exhibit different organizational and environmental characteristics, which, in turn, might influence their performance (Wiklund \& Sepherd, 2005). Following NACE coding (statistical classification of economic activities in the European Community), we introduced three dummy variables (manufacturing, construction, and services), with the primary sector employed as the default. Sixth, we controlled for firm age by calculating the number of years that the firm had been operating (2015 - constitution year of business), similar to previous studies (e.g., Zahra, 2012). Seventh, we controlled for the existence of strategic planning (Eddleston et al., 2008) by asking if the firm had a strategic plan that included both business goals and the resources and capabilities required to achieve them, with a dichotomous response format. $\mathrm{Fi}$ nally, we controlled for environmental dynamism $($ Cronbach's alpha $=0.808)$, which refers to the frequency of changes, the difference involved in each change, and the irregularity in the overall pattern of change characterizing organizational environment (Child, 1972), using a three-item index taken from Jansen, Van den Bosch, and Volberda (2005).

\section{Statistical analysis}

The analysis of data retrieved through surveys has been performed in two steps. First, we performed a multiple regression analysis by distinguishing family and non-family firms. Second, we applied the Chow test, which aims to test the equality of sets of coefficients in two regressions (Chow, 1960; Toyoda, 1974) and has been used previously in the family business area (e.g., Zahra et al., 2004).

\section{Results and Discussion}

The means, standard deviations, and zero-order correlations are shown in Table 2. All correlation coefficients are smaller than 0.62 and, hence, smaller than the recommended threshold of 0.65 (Tabachnick \& Fidell, 2012), except for the correlation between EO and LO; their variance inflation factors were 2.315 and 2.043, respectively, and, thus, under the suggested threshold (Hair, Anderson, Tatham, \& Black, 1998). Therefore, multicollinearity does not appear to be a serious concern.

Hypotheses 1 to 3 were tested using multiple regression analysis. Results appear in Table 3, where Models A1 and A2 refer to the group of family firms. When performance was regressed on the control variables (Model A1), the results were significant, the model explained 8.5 percent of the variance $(p<0.001)$, and five of the eight control variables were significantly related to organizational performance. These were country $(b=$ $0.121, p<0.05)$, size $(b=0.092, p<0.05)$, firm age $(b=-0.006, p<0.01)$, strategic planning $(b=$ $0.253, p<0.001)$, and environmental dynamism ( $b$ $=0.085, p<0.01$ ).

With regards to the impact of strategic orientations on organizational performance (Hypotheses 1 through 3), we entered the EO, LO, and MO constructs in Model A2. A significant change in $\mathrm{R}^{2}$ was observed in Model A2 $\left(\Delta R^{2}=0.151, p<0.001\right)$. Hypothesis 1 proposed that higher EO would promote higher organizational performance for family firms. According to Model A2, EO showed a significant positive effect on family firm performance (b $=0.449, \mathrm{p}<0.001$ ), supporting Hypothesis 1 and confirming the findings of previous studies (e.g., Chien, 2014; Schepers et al., 2014).

With respect to the influence of LO on organizational performance, Hypothesis 2 proposed that this influence would be positive for family firms. 
Table 2. Descriptive statistics and correlations

\begin{tabular}{|c|c|c|c|c|c|c|c|c|c|c|c|c|c|c|}
\hline & & Mean & S.D. & 1 & 2 & 3 & 4 & 5 & 6 & 7 & 8 & 9 & 10 & 11 \\
\hline 1 & Performance & 3.486 & 0.673 & & & & & & & & & & & \\
\hline 2 & $\begin{array}{l}\text { Entrepreneurial } \\
\text { orientation }\end{array}$ & 3.822 & 0.539 & $0.442^{* * *}$ & & & & & & & & & & \\
\hline 3 & $\begin{array}{l}\text { Learning } \\
\text { orientation }\end{array}$ & 3.967 & 0.555 & $0.322^{* * *}$ & $0.675^{* * *}$ & & & & & & & & & \\
\hline 4 & Market orientation & 3.999 & 0.609 & $0.328^{* * *}$ & $0.519^{* * *}$ & $0.619^{* * *}$ & & & & & & & & \\
\hline 5 & Country & 0.522 & 0.500 & $-0.032^{* * *}$ & $0.090^{* *}$ & 0.030 & -0.042 & & & & & & & \\
\hline 6 & Firm size $^{y}$ & 3.217 & 0.783 & $0.088^{* *}$ & 0.005 & $-0.056^{*}$ & $0.079^{* *}$ & 0.004 & & & & & & \\
\hline 7 & $\begin{array}{l}\text { Manufacturing } \\
\text { sector }\end{array}$ & 0.276 & 0.447 & $-0.017^{*}$ & -0.048 & $-0.058^{*}$ & $-0.051^{*}$ & $0.111^{* * *}$ & $0.130^{* * *}$ & & & & & \\
\hline 8 & $\begin{array}{l}\text { Construction } \\
\text { sector }\end{array}$ & 0.088 & 0.284 & $-0.071^{*}$ & -0.050 & -0.036 & -0.022 & -0.021 & -0.029 & $-0.192^{* * *}$ & & & & \\
\hline 9 & Services sector & 0.612 & 0.488 & $0.060^{*}$ & $0.082^{* *}$ & $0.082^{* *}$ & $0.093^{* *}$ & $-0.087^{* *}$ & $-0.098^{* *}$ & $-0.774^{* * *}$ & $-0.390^{* * *}$ & & & \\
\hline 10 & Firm age & 23.060 & 14.402 & $-0.086^{* *}$ & $-0.058^{*}$ & $-0.064^{*}$ & -0.024 & $0.071^{*}$ & $0.233^{* * *}$ & $0.160^{* * *}$ & -0.020 & $-0.111^{* * *}$ & & \\
\hline 11 & $\begin{array}{l}\text { Strategic } \\
\text { planning }\end{array}$ & 0.66 & 0.473 & $0.220^{* * *}$ & $0.222^{* * *}$ & $0.152^{* * *}$ & $0.176^{* * *}$ & $0.213^{* * *}$ & $0.163^{* * *}$ & 0.020 & $-0.078^{* *}$ & 0.028 & -0.022 & \\
\hline 12 & $\begin{array}{l}\text { Environmental } \\
\text { dynamism }\end{array}$ & 3.653 & 0.909 & $0.169^{* * *}$ & $0.394^{* * *}$ & $0.358^{* * *}$ & $0.273^{* * *}$ & 0.041 & 0.007 & $-0.077^{* *}$ & -0.039 & $0.118^{* * *}$ & -0.013 & $0.084^{* *}$ \\
\hline
\end{tabular}

This hypothesis was not supported $(b=-0.041$, n.s.). The fact that the association between LO and (family and non-family) firm performance was not statistically significant is in line with prior research on service organizations (Lam et al., 2011) and stresses the need to analyze the relationships among strategic orientations (Deutscher et al., 2016), given the empirical evidences that LO may boost (for instance) EO (Hernández-Linares et al., 2018a)

Hypothesis 3, which proposed a positive direct association between $\mathrm{MO}$ and performance for family firms, was supported $(b=0.163$, $p<$ 0.01 ). MO contributes to family business performance, which seems to indicate that family firms are capable of transforming their MO into performance. This may be explained because family firms are good both at having strong relationships with their clients and establishing long-term relationships with their stakeholders (Arregle, Hitt, Sirmon, \& Very, 2007; Cabrera-Suárez, Déniz-Déniz, \& Martín-Santana, 2011). This allows them to identify and satisfy the market demands with less effort and more success than can their nonfamily counterparts.

Hypothesis 4 was tested using the Chow test (Chow, 1960) to determine the significance of the differences across the two subgroups (family and non-family firms) in the effect of the three independent variables on organizational performance. Before calculating the Chow test, we included Models B1 and B2 that performed the same regression analysis using the non-family firms' subsample. The model B1 was significant and explained 11.2 percent of the variance $(p$ $<0.001$ ), and two of the eight control variables were significantly related to organizational performance. These were strategic planning $(b=$ 0.326, $p<0.001$ ) and environmental dynamism $(b=0.138, p<0.01)$. Regarding the effect of the strategic orientations on the non-family firms' performance, Model B2 was significant $\left(\Delta R^{2}\right.$ $=0.141, \mathrm{p}<0.001)$, but only EO contributed to non-family firms performance $(b=0.478, p<$ $0.001)$, whereas both LO ( $p=0.022$, n.s. $)$ and $M O$ $(p=0.085, n . s$.) did not contribute to non-family firms' performance. These results points toward a different strategic behavior of family and nonfamily firms because only EO is significant for the performance for non-family firms, whereas $M O$ is also relevant for family firms, despite EO being the more significant strategic orientation.

Despite the strategic differences identified, the results of the Chow test show that there are no significant statistical differences between family and non-family firms in the positive effect of strategic orientations on firm performance $(F=$ 0.6625; $p>0.05$ ), thereby supporting Hypothesis 4. These findings are in line with the idea of strategic equifinality (Carney et al., 2015); that is, our findings imply that, even if family and non-family firms employ different combinations of EO, LO, and $\mathrm{MO}$, these combinations do not have different impacts on the organizational performance of both subgroups of the population (family and non-family firms). 
Table 3. Results of linear regression analysis: four models*

Variables

Variables
Controls:
Country
Size ${ }^{1}$
Manufacturing sector
Construction sector
Services sector
Age
Strategic planning
Environmental dynamism
Independent variables:
EO
LO
MO
$\Delta \mathbf{R}^{2}$
$\mathrm{R}^{2}$
Adjusted $\mathrm{R}^{2}$
$\mathrm{~F} \quad$

Chow test
Models
Model A (FBs)

A1

$-0.121^{*}$
$0.092^{*}$
-0.162
-0.287
-0.167
$-0.006^{* *}$
$0.253^{* * *}$
$0.085^{* *}$

$-0.121^{*}$

0.162

0.287

$0.006^{* *}$

$0.253^{* * *}$

$\begin{array}{lc} & 0.449^{* * *} \\ & -0.041 \\ & 0.163^{* *} \\ 0.085^{* * *} & 0.151^{* * *} \\ 0.085 & 0.236 \\ 0.073 & 0.222\end{array}$

A2

$-0.90^{\dagger}$

$0.074^{*}$

$-0.110$

$-0.221$

$-0.133$

$-0.004^{* *}$

$0.111^{*}$

$-0.033$
Model B (NFBs)

B1

B2

$\begin{array}{cc}-0.90 & -0.145^{*} \\ 0.039 & 0.050 \\ 0.300 & 0.114 \\ 0.198 & 0.004 \\ 0.319 & 0.108 \\ -0.002 & -0.003 \\ 0.326^{* * *} & 0.249^{* * *} \\ 0.138^{* * *} & 0.014\end{array}$

$0.478^{* * *}$

0.022

0.085

$0.112^{* * *} \quad 0.141^{* * *}$

0.120

0.254

0.096

0.235

$13.749^{* * *}$
$F=0.662535$

" logarithm of the number of employees; ${ }^{\dagger} p<0.05-, p<0.05 ;{ }^{* *} p<0.01$; ${ }^{* * *} p<0.001$

\section{Conclusions, Practical Implications, Limita- tions, and Future Research Lines}

Based on a sample of 1,066 Portuguese and Spanish SMEs, this work analyzes the impact of EO, $\mathrm{LO}$, and $\mathrm{MO}$ on the organizational performance of family firms. We assumed that a firm may follow different types of strategic orientations simultaneously and that each orientation should not be viewed in isolation (e.g., Lonial \& Carter, 2015). Thus, our work provides empirical evidence that EO is the strategic orientation with higher positive influence on the organizational performance of family firms (also for non-family firms), followed by MO (which does not contribute to nonfamily firms' performance), whereas LO does not impact on their performance.

This article confirms the need to differentiate between family firms and non-family firms when strategic orientations are analyzed and makes three contributions to the literature. First, our work joins the small group of investigations that apply the alternative approach (Hakala, 2011) and to the studies analyzing the parallel direct effect of strategic orientations on performance (Deutscher et al., 2016) and also highlights the importance of strategic orientations for value creation in enterprise organizations.
Moreover, to date, the literature on the interplay of EO, LO, and MO has been amiss in relation to the influence of family status on firm performance. Therefore, the second contribution of this study lies in providing empirical evidence that the family character of the firm determines the relationship between strategic orientations (mainly, EO, LO, and MO) and business performance. Specifically, we have found that even if $M O$ is only significant for the performance of family firms, overall this situation does not lead to a different performance between family and non-family firms. This result confirms that the different strategic behaviors of family and nonfamily firms may have a similar effect on performance, which is the rationale under the strategic equifinality idea (Carney et al., 2015; Gresov \& Drazin, 1997; Payne, 2006). These results add empirical evidence to the emerging chorus of scholars demanding a more fine grained analysis of the differences between family and nonfamily firms (Carney et al., 2015; O'Boyle et al., 2012) and may be explained, in line with Carney et al. (2015), by the greater variability that family firms exhibit with respect to their strategic preferences versus those of non-family firms (Chrisman \& Patel, 2012; Gedajlovic, Lubatkin, \& Schulze, 2004), which will require additional 
research in the future. Despite the popularity of discussions of singularities of family firms with respect to the sharing and transfer of knowledge (Chirico, 2008; Zahra et al., 2007), no prior studies have examined the relationship between LO and family firm performance. This study offers an initial effort in this regard and, when considered together with the recent works that have found a boosting role of LO on EO within family firms (Hernández-Linares et al, 2018a), suggests that the effect of LO on performance is not direct but may be mediated by EO. That lays a foundation for a more thorough examination of this complex issue in future studies. Third, the study offers some preliminary results on the effect of $\mathrm{MO}$ on firm performance in family firms versus non-family firms in the SME context, thus filling a gap in the literature. We consider that family businesses are better at promoting a stronger $\mathrm{MO}$ and taking advantage of it in terms of organizational performance because the "good name of the company" is often linked to the "good name of the family." Reputation constitutes a key organizational asset (Fombrun, 1996), especially in the case of family firms as they tend to establish long-term relationships with their stakeholders (Arregle et al., 2007; Cabrera-Suárez et al., 2011). The image is often linked to corporate strategy (Dyer \& Whetten, 2006) and MO is probably the strategic orientation more related to the good image between the clients. Our findings confirm Zachary and colleagues' (2011) suggestion that MO is a potentially useful concept to better understand the impact of family-based idiosyncrasies on business strategies and organizational outcomes, thereby highlighting the need for further examination of the influence of family business nature on MO.

In addition, our findings have important practical implications for organizations, especially for family firms. First, they shed light on where best to focus the business efforts to improve performance considering the organizational context. One of the study's key findings is that strategic orientations have a strong and significant impact on family firms' performance, this being the first study that empirically confirms that family firms also may employ multiple strategic orientations for improved organizational performance. Consequently, family firms' managers should identify, understand, and use strategic orientations that improve the organizational performance. Second, this is also the first study that empirically confirms that there is a best strategic orientation (EO) for family firms' performance. Therefore, both family and non-family firms' managers need to establish systems and structures that give employees the opportunity to contribute to entrepreneurship (Zahra et al., 2004), for example, by promoting an entrepreneurial culture based on fomenting curiosity and fostering and scanning the external environments to anticipate changes in marketplace trends, taking risks and showing initiative, or establishing organizational structures with decision systems that give more freedom and responsibility to members of the company. Third, this is one of the first studies empirically analyzing LO in the family business context. The fact that the influence of LO on family firms' performance has not been found significant may justify the need for deep analysis of this relationship. Such as by considering that LO is a multidimensional construct and that different LO's dimensions could have different impacts on firm performance, the negative effects of one may, in this way, be neutralized by the positive effects of others. And also by exploring the possibility that EO mediates the LO-performance link. Fourth, once the EO is developed in the organization, family firms' managers need to promote a market-oriented culture, as they have been found to be better than are their non-family counterparts at gaining advantage from MO. Finally, our findings seem to corroborate the idea of strategic equifinality (Carney et al., 2015; Gresov \& Drazin, 1997; Payne, 2006) and that managers should adapt their strategic behavior depending on the type of firm that they manage.

Although this study provides valuable contributions to the literature in this field, it is not exempt from limitations. However, some of these limitations suggest promising avenues for future investigations. First, though cross-sectional designs are common in family business literature (e.g., Casillas et al., 2010; Stanley et al., 2019), the fact that the data for this investigation were gathered at one point in time does not allow us to infer causality from our findings; a limitation that could be overcome with longitudinal studies. Second, as this study used a single-informant approach, future research could use either archival data or other sources of information to examine the influence of these three strategic orientations on performance more accurately. Third, because our data consisted of Spanish and Portuguese SMEs, generalizing our findings should be done with some caution, because national culture and traditions may influence the strategic behaviors or orientations of SMEs (Kreiser, Marino, Kuratko, \& Weaver, 2013). For instance, some national cultures encourage risk-taking, whereas others reduce managers' willingness to pursue entrepreneurial activities (Zahra et al., 2004). Moreover one should note that the data were collected in 2015, a year in which both Spain and Portugal were still deeply immersed in an economic crisis. Therefore, we suggest strongly that our model be applied in other countries and/or cultures. Fourth, we used self-assessment and perceived measures for the three strategic 
orientations and for organizational performance. Consequently, our data could be biased and reflect hopeful thinking rather than a factual state. Fifth, we employed self-perception as a family firm and the percentage of family ownership to distinguish between family and non-family firms; however, considering the diversity of family firm definitions (e.g., Hernández-Linares et al., 2017, 2018b), others definitional criteria could be used. In a similar sense, considering that family firms are heterogeneous (Chua, Chrisman, Steier, \& Rau, 2012) and that there is a growing body of evidence that different types of family firms vary with respect to their strategic choices and relative performance (Miller, Le Breton-Miller, \& Lester, 2011; Schulze, Lubatkin, \& Dino, 2003; Stanley et al., 2019), our analysis could be refined by including different types of family firms. Moreover, we used organizational performance as a dependent variable; however, other endogenous variables, such as innovation, customer satisfaction, or firm internationalization, could also be explored. At present, a considerable gap remains in our understating of how either firm generation or generational involvement either mediates or moderates the relationship between strategic orientations and performance outcomes. Family firms evolve across generations, and their risktaking preferences also evolve (Autio \& Mustakallio, 2003). Therefore, a promising sixth research line lies in exploring both the role these generational differences play in influencing strategic orientations of family firms and their impact on organizational performance. Finally, considering the three approaches to the study of strategic orientations from Hakala (2011), the sequential and complementary approaches should also be explored.

Family business literature has grown rapidly in the last few decades, but the developing literature has many research gaps (Benavides-Velasco, Quintana-García, \& Guzmán-Parra, 2013; Carney et al., 2015). One of these gaps is the simultaneous development of different strategic orientations. The broad picture of the strategic orientations in family firms that emerge from this study makes important contributions to the literature and has important practical implications; however, our overall aim is to create a starting point that promotes further investigation.

\section{References}

Arend, R. J. (2013). Ethics-focused dynamic capabilities: a small business perspective. Small Business Economics, 41(1), 1-24.

Arregle, J. L., Hitt, M. A., Sirmon, D. G., and Very, P. (2007). The development of organizational social capital: Attributes of family firms. Journal of Management Studies, 44(1), 73-95.
Autio, E., and Mustakallio, M. (2003, December). Family firm internationalization: A model of family firm generational succession and internationalization strategic postures. Paper presented at the Theories of the Family Enterprise Conference, Philadelphia, United States of America.

Baker, W. E., and Sinkula, J. M. (1999). The synergistic effect of market orientation and learning orientation on organizational performance. Journal of the Academy of Marketing Science, 27(4), 411-427.

Baker, W. E., and Sinkula, J. M. (2009). The complementary effects of market orientation and entrepreneurial orientation on profitability in small businesses. Journal of Small Business Management, 47(4), 443-464.

Barros, I., Hernangómez, J., and Martin-Cruz, N. (2017). Familiness and socioemotional wealth in Spanish family firms: An empirical examination. European Journal of Family Business, 7(1-2), 14-24. doi: 10.1016/j.ejfb.2017.06.004

Beck, L., Janssens, W., Debruyne, M., and Lommelen, T. (2011). A study of the relationships between generation, market orientation, and innovation in family firms. Family Business Review, 24(3), 252272.

Benavides-Velasco, C. A., Quintana-García, C., and Guzmán-Parra, V. F. (2013). Trends in family business research. Small Business Economics, 40(1), 4157.

Bhuian, S. N. (1997). Exploring market orientation in banks: An empirical examination in Saudi Arabia. Journal of Services Marketing, 11(5), 317-328.

Cabrera-Suárez, M. K., Déniz-Déniz, M. C., and Martín-Santana, J. D. (2011). Familiness and market orientation: A stakeholder approach. Journal of Family Business Strategy, 2(1), 34-42.

Cabrera-Suárez, K., De Saá-Pérez, P., and GarcíaAlmeida, D. (2001). The succession process from a resource-and knowledge-based view of the family firm. Family Business Review, 14(1), 37-46.

Cadogan, J. W. (2012). International marketing, strategic orientations and business success: Reflections on the path ahead. International Marketing Review, 29(4), 340-348.

Calantone, R. J., Cavusgil, S. T., and Zhao, Y. (2002). Learning orientation, firm innovation capability, and firm performance. Industrial Marketing Management, 31(6), 515-524.

Cameron, K. (1978). Measuring organizational effectiveness in institutions of higher education. Administrative Science Quarterly, 23(4), 604-632.

Carney, M., van Essen, M., Gedajlovic, E. R., and Heugens, P. P. (2015). What do we know about private family firms? A meta-analytical review. Entrepreneurship: Theory \& Practice, 39(3), 513-544.

Casillas, J. C., Moreno, A. M., and Barbero, J. L. (2010). A configurational approach of the relationship between entrepreneurial orientation and growth of family firms. Family Business Review, 23(1), 27-44.

Casillas, J. C., Moreno, A. M., and Barbero, J. L. (2011). Entrepreneurial orientation of family firms: Family and environmental dimensions. Journal of Family Business Strategy, 2(2), 90-100.

Chien, S. Y. (2014). Franchisor resources, spousal resources, entrepreneurial orientation, and perfor- 
mance in a couple-owned franchise outlet. Management Decision, 52(5), 916-933.

Child, J. (1972). Organizational structure, environment and performance: The role of strategic choice. Sociology, 6(1), 1-22.

Chirico, F. (2008). Knowledge accumulation in family firms evidence from four case studies. International Small Business Journal, 26(4), 433-462.

Chow, G. C. (1960). Tests of equality between sets of coefficients in two linear regressions. Econometrica, 28, 591-605.

Chrisman, J. J., Chua, J. H., Pearson, A. W., and Barnett, T. (2012). Family involvement, family influence, and family-centered non-economic goals in small firms. Entrepreneurship: Theory \& Practice, 36(2), 267-293.

Chrisman, J. J., and Patel, P. C. (2012). Variations in R\&D investments of family and nonfamily firms: Behavioral agency and myopic loss aversion perspectives. Academy of Management Journal, 55(4), 976-997.

Covin, J. G., and Slevin, D. P. (1989). Strategic management of small firms in hostile and benign environments. Strategic Management Journal, 10(1), 75-87.

Covin, J. G., and Wales, W. J. (2012). The measurement of entrepreneurial orientation. Entrepreneurship: Theory \& Practice, 36(4), 677-702.

Chua, J. H., Chrisman, J. J., Steier, L. P., and Rau, S. B. (2012). Sources of heterogeneity in family firms: An introduction. Entrepreneurship: Theory \& Practice, 36(6), 1103-1113.

Deshpandé, R., Farley, J. U., and Webster Jr., F. E. (1993). Corporate culture, customer orientation, and innovativeness in Japanese firms: A quadrad analysis. The Journal of Marketing, 57(1), 23-37.

Dess, G. G., and Robinson, R. B. (1984). Industry effects and strategic management research. Journal of Management, 16(7), 7-27.

Deutscher, F., Zapkau, F. B., Schwens, C., Baum, M., and Kabst, R. (2016). Strategic orientations and performance: A configurational perspective. Journal of Business Research, 69(2), 849-861.

Dyer, W. G., and Whetten, D. A. (2006). Family firms and social responsibility: Preliminary evidence from the S\&P 500. Entrepreneurship: Theory \& Practice, 30(6), 785-802.

Eddleston, K. A., Kellermanns, F. W., and Sarathy, R. (2008). Resource configuration in family firms: Linking resources, strategic planning and technological opportunities to performance. Journal of Management Studies, 45(1), 26-50.

Farrell, M. A., Oczkowski, E., and Kharabsheh, R. (2008). Market orientation, learning orientation and organisational performance in international joint ventures. Asia Pacific Journal of Marketing and Logistics, 20(3), 289-308.

Fombrun, C. J. (1996). Reputation: Realizing Value from the Corporate Image. Boston: Harvard Business School Press.

Galego, A., Mira, N., and Vidigal da Silva, J. (2018). Ownership, productivity and firms' life-cycle. European Journal of Family Business, 8(2), 139-150. doi: 10.24310/ejfbejfb.v8i2.5228

Gedajlovic, E., and Carney, M. (2010). Markets, hierarchies, and families: Toward a transaction cost theory of the family firm. Entrepreneurship: Theory \& Practice, 34(6), 1145-1172.
Gedajlovic, E., Carney, M., Chrisman, J. J., and Kellermanns, F. W. (2012). The adolescence of family firm research: Taking stock and planning for the future. Journal of Management, 38(4), 1010-1037.

Gedajlovic, E., Lubatkin, M. H., and Schulze, W. S. (2004). Crossing the threshold from founder management to professional management: A governance perspective. Journal of Management Studies, 41(5), 899-912.

Greenley, G. E. (1995). Market orientation and company performance: Empirical evidence from UK companies. British Journal of Management, 6(1), 1-13.

Gresov, C., and Drazin, R. (1997). Equifinality: Functional equivalence in organization design. Academy of Management Review, 22(2), 403-428.

Grewal, R., and Tansuhaj, P. (2001). Building organizational capabilities for managing economic crisis: The role of market orientation and strategic flexibility. Journal of Marketing, 65(2), 67-80.

Habbershon, T. G., and Williams, M. L. (1999). A resource-based framework for assessing the strategic advantages of family firms. Family Business Review, 12(1), 1-25.

Hair, J. F., Anderson, R. E., Tatham, R. L., and Black, W. C. (1998). Multivariate Data Analysis. Upper Saddle River, NJ: Prentice Hall.

Hakala, H. (2011). Strategic orientations in management literature: Three approaches to understanding the interaction between market, technology, entrepreneurial and learning orientations. International Journal of Management Reviews, 13(2), 199-217.

Hernández-Linares, R., Kellermanns, F. W., and López-Fernández, M. C. (2018a). A note of the relationships between learning, market, and entrepreneurial orientations: The family business influence. Journal of Family Business Strategy, 9(3), 192-204.

Hernández-Linares, R., Kellermanns, F. W., LópezFernández, M. C., and Sarkar, S. (2019). The effect of socioemotional wealth on the relationship between entrepreneurial orientation and family business performance. BRQ Business Research Quarterly. doi: 10.1016/j.brq.2019.03.002

Hernández-Linares, R., and López-Fernández, M. C. (2018). Entrepreneurial orientation and the family firm: Mapping the field and tracing a path for future research. Family Business Review, 31(3), 318351.

Hernández-Linares, R., Sarkar, S., and Cobo, M. J. (2018b). Inspecting the Achilles heel: A quantitative analysis of 50 years of family business definitions. Scientometrics, 115(2), 929-951.

Hernández-Linares, R., Sarkar, S., and LópezFernández, M. C. (2017). How has the family firm literature addressed its heterogeneity through classification systems? An integrated analysis. European Journal of Family Business, 7(1-2), 1-13. doi: 10.1016/j.ejfb.2017.06.003

Hofstede, G. (2001). Culture's Consequences: Comparing Values, Behavior, Institutions, and Organizations across Nations ( $2^{\text {nd }} e d$.). Thousand Oaks, CA: Sage.

Hughes, M., and Morgan, R. E. (2007). Deconstructing the relationship between entrepreneurial orientation and business performance at the embryonic stage of firm growth. Industrial Marketing Management, 36(5), 651-661. 
Hult, G. T. M., Nichols Jr, E. L., Giunipero, L. C., and Hurley, R. F. (2000). Global organizational learning in the supply chain: A low versus high learning study. Journal of International Marketing, 8(3), 6183.

Irava, W., and Moores, K. (2010). Resources supporting entrepreneurial orientation in multigenerational family firms. International Journal of Entrepreneurial Venturing, 2(3/4), 222-245.

Jansen, J. J., Van Den Bosch, F. A., and Volberda, H. W. (2005). Managing potential and realized absorptive capacity: How do organizational antecedents matter? Academy of Management Journal, 48(6), 999-1015.

Jaworski, B. J., and Kohli, A. K. (1993). Market orientation: Antecedents and consequences. The Journal of Marketing, 57(3), 53-70.

Keh, H. T., Nguyen, T. T. M., and Ng, H. P. (2007). The effects of entrepreneurial orientation and marketing information on the performance of SMEs. Journal of Business Venturing, 22(4), 592-611.

Kellermanns, F. W., and Eddleston, K. A. (2006). Corporate entrepreneurship in family firms: A family perspective. Entrepreneurship: Theory \& Practice, 30(6), 809-830.

Kellermanns, F. W., Eddleston, K. A., Sarathy, R., and Murphy, F. (2012). Innovativeness in family firms: A family influence perspective. Small Business Economics, 38(1), 85-101.

Kirca, A. H., Jayachandran, S., and Bearden, W. 0. (2005). Market orientation: A meta-analytic review and assessment of its antecedents and impact on performance. Journal of Marketing, 69(2), 24-41.

Kohli, A. K., and Jaworski, B. J. (1990). Market orientation: The construct, research propositions, and managerial implications. The Journal of Marketing, 54(April), 1-18.

Kohli, A. K., Jaworski, B. J., and Kumar, A. (1993). MARKOR: A measure of market orientation. Journal of Marketing Research, 30(November), 467-477.

Kotlar, J., and De Massis, A. (2013). Goal setting in family firms: Goal diversity, social interactions, and collective commitment to family-centered goals. Entrepreneurship: Theory \& Practice, 37(6), 12631288.

Kraiczy, N. D., Hack, A., and Kellermanns, F. W. (2014). New product portfolio performance in family firms. Journal of Business Research, 67(6), 1065-1073.

Kreiser, P. M., Marino, L. D., Kuratko, D. F., and Weaver, K. M. (2013). Disaggregating entrepreneurial orientation: The non-linear impact of innovativeness, proactiveness and risk-taking on SME performance. Small Business Economics, 40(2), 273-291.

Kropp, F., Lindsay, N. J., and Shoham, A. (2006). Entrepreneurial, market, and learning orientations and international entrepreneurial business venture performance in South African firms. International Marketing Review, 23(5), 504-523.

Kumar, V., Jones, E., Venkatesan, R., and Leone, R. P. (2011). Is market orientation a source of sustainable competitive advantage or simply the cost of competing? Journal of Marketing, 75(1), 16-30.

Lam, S. Y., Lee, V. H., Ooi, K. B., and Lin, B. (2011). The relationship between TQM, learning orientation and market performance in service organisations:
An empirical analysis. Total Quality Management \& Business Excellence, 22(12), 1277-1297.

Lee, T., and Chu, W. (2017). The relationship between entrepreneurial orientation and firm performance: Influence of family governance. Journal of Family Business Strategy, 8(4), 213-223.

Lin, C. H., Peng, C. H., and Kao, D. T. (2008). The innovativeness effect of market orientation and learning orientation on business performance. International Journal of Manpower, 29(8), 752-772.

Lonial, S. C., and Carter, R. E. (2015). The impact of organizational orientations on medium and small firm performance: A resource-based perspective. Journal of Small Business Management, 53(1), 94-113.

Lumpkin, G. T., Brigham, K. H., and Moss, T. W. (2010). Long-term orientation: Implications for the entrepreneurial orientation and performance of family businesses. Entrepreneurship \& Regional Development, 22(3-4), 241-264.

Lumpkin, G. T., and Dess, G. G. (1996). Clarifying the entrepreneurial orientation construct and linking it to performance. Academy of Management Review, 21(1), 135-172.

Madison, K., Runyan, R. C., and Swinney, J. L. (2014). Strategic posture and performance: Revealing differences between family and nonfamily firms. Journal of Family Business Strategy, 5(3), 239-251.

Martínez, J. I., Stöhr, B. S., and Quiroga, B. F. (2007). Family ownership and firm performance: Evidence from public companies in Chile. Family Business Review, 20(2), 83-94.

Matsuno, K., Mentzer, J. T., and Özsomer, A. (2002). The effects of entrepreneurial proclivity and market orientation on business performance. Journal of Marketing, 66(3), 18-32.

Mavondo, F. T., Chimhanzi, J., and Stewart, J. (2005). Learning orientation and market orientation: Relationship with innovation, human resource practices and performance. European Journal of Marketing, 39(11/12), 1235-1263.

Mazzola, P., Sciascia, S., and Kellermanns, F. W. (2013). Non-linear effects of family sources of power on performance. Journal of Business Research, 66(4), 568-574.

Miller, D. (1983). The correlates of entrepreneurship in three types of firms. Management Science, 29(7), 770-791.

Miller, D., Le Breton-Miller, I., and Lester, R. H. (2011). Family and lone founder ownership and strategic behaviour: Social context, identity, and institutional logics. Journal of Management Studies, 48(1), 1-25.

Miller, D., Steier, L., and Le Breton-Miller, I. (2016). What can scholars of entrepreneurship learn from sound family businesses? Entrepreneurship: Theory \& Practice, 40(3), 445-455.

Morgan, N. A., Vorhies, D. W., and Mason, C. H. (2009). Market orientation, marketing capabilities, and firm performance. Strategic Management Journal, 30(8), 909-920.

Naldi, L., Nordqvist, M., Sjöberg, K., and Wiklund, J. (2007). Entrepreneurial orientation, risk taking, and performance in family firms. Family Business Review, 20(1), 33-47.

Narver, J. C., and Slater, S. F. (1990). The effect of a market orientation on business profitability. The Journal of Marketing, 54(4), 20-35. 
Newman, A., Prajogo, D., and Atherton, A. (2016). The influence of market orientation on innovation strategies. Journal of Service Theory and Practice, 26(1), 72-90.

Nunnally, J. C. (1978). Psychometric Theory. New York, NY: McGraw-Hill.

O'Boyle, E. H. Jr., Pollack, J. M., and Rutherford, M. W. (2012). Exploring the relation between family involvement and firms' financial performance: A meta-analysis of main and moderator effects. Journal of Business Venturing, 27(1), 1-18.

Payne, G. T. (2006). Examining configurations and firm performance in a suboptimal equifinality context. Organization Science, 17(6), 756-770.

Prusak, L. (1996). The knowledge advantage. Planning Review, 24(2), 6-8.

Rauch, A., Wiklund, J., Lumpkin, G. T., and Frese, M. (2009). Entrepreneurial orientation and business performance: An assessment of past research and suggestions for the future. Entrepreneurship: Theory \& Practice, 33(3), 761-787.

Real, J. C., Roldán, J. L., and Leal, A. (2014). From entrepreneurial orientation and learning orientation to business performance: Analysing the mediating role of organizational learning and the moderating effects of organizational size. British Journal of Management, 25(2), 186-208.

Revilla, A. J., Pérez-Luño, A., and Nieto, M. J. (2016). Does family involvement in management reduce the risk of business failure? The moderating role of entrepreneurial orientation. Family Business Review, 29(4), 365-379.

Rodríguez, C., Carrillat, F. A., and Jaramillo, F. (2004). A meta-analysis of the relationship between market orientation and business performance: Evidence from five continents. International Journal of Research in Marketing, 21(2), 179-200.

Schepers, J., Voordeckers, W., Steijvers, T., and Laveren, E. (2014). The entrepreneurial orientation-performance relationship in private family firms: The moderating role of socioemotional wealth. Small Business Economics, 43(1), 39-55.

Schulze, W. S., Lubatkin, M. H., and Dino, R. N. (2003). Exploring the agency consequences of ownership dispersion among the directors of private family firms. Academy of Management Journal, 46(2), 179-194.

Sharma, P., Chrisman, J. J., and Gersick, K. E. (2012). 25 years of family business review: Reflections on the past and perspectives for the future. Family Business Review, 25(1), 5-15.

Sinkula, J. M., Baker, W. E., and Noordewier, T. (1997). A framework for market-based organizational learning: Linking values, knowledge, and behavior. Journal of the Academy of Marketing Science, 25(4), 305-318.

Slevin, D. P., and Covin, J. G. (1990). Juggling entrepreneurial style and organizational structure. Sloan Management Review, 31(2), 43-53.

Stanley, L. J., Hernández-Linares, R., López-Fernández, M. C., and Kellermanns, F. W. (2019). A typology of family firms: An investigation of entrepreneurial orientation and performance. Family Business Review, 32(2), 174-194.

Tabachnick, B. G., and Fidell, L. S. (2012). Using Multivariate Statistics ( $6^{\text {th }}$ ed). Boston, MA: Pearson Education.
Tokarczyk, J., Hansen, E., Green, M., and Down, J. (2007). A resource-based view and market orientation theory examination of the role of "familiness" in family business success. Family Business Review, 20(1), 17-31.

Toyoda, T. (1974). Use of the Chow test under heteroscedasticity. Econometrica: Journal of the Econometric Society, 42(3), 601-608.

Wang, C. L. (2008). Entrepreneurial orientation, learning orientation, and firm performance. Entrepreneurship: Theory \& Practice, 32(4), 635-657.

Wiklund J. (1999). The sustainability of the entrepreneurial orientation-performance relationship. Entrepreneurship: Theory \& Practice, 24(1), 37-48.

Wiklund, J., and Shepherd, D. (2003). Research notes and commentaries: Knowledge-based resources, entrepreneurial orientation, and the performance of small and medium-sized businesses. Strategic Management Journal, 24(13), 1307-1314.

Wiklund, J., and Shepherd, D. (2005). Entrepreneurial orientation and small business performance: A configurational approach. Journal of Business Venturing, 20(1), 71-91.

Zahra, S. A. (2012). Organizational learning and entrepreneurship in family firms: Exploring the moderating effect of ownership and cohesion. Small Business Economics, 38(1), 51-65.

Zahra, S. A., and Covin, J. G. (1995). Contextual influences on the corporate entrepreneurship-performance relationship: A longitudinal analysis. Journal of Business Venturing, 10(1), 43-58.

Zahra, S. A., Hayton, J. C., Neubaum, D. O., Dibrell, C., and Craig, J. (2008). Culture of family commitment and strategic flexibility: The moderating effect of stewardship. Entrepreneurship: Theory \& Practice, 32(6), 1035-1054.

Zahra, S. A., Hayton, J. C., and Salvato, C. (2004). Entrepreneurship in family vs. non-family firms: A resource-based analysis of the effect of organizational culture. Entrepreneurship: Theory \& Practice, 28(4), 363-381.

Zahra, S. A., Ireland, R. D., and Hitt, M. A. (2000). International expansion by new venture firms: International diversity, mode of market entry, technological learning, and performance. Academy of Management Journal, 43(5), 925-950.

Zahra, S. A., Neubaum, D. O., and Larrañeta, B. (2007). Knowledge sharing and technological capabilities: The moderating role of family involvement. Journal of Business Research, 60(10), 10701079.

Zachary, M. A., McKenny, A., Short, J. C., and Payne, G. T. (2011). Family business and market orientation construct validation and comparative analysis. Family Business Review, 24(3), 233-251. 